\title{
LITERATUR REVIEW : $E$-LEARNING DAN APLIKASINYA DALAM BIDANG PENDIDIKAN KEPERAWATAN
}

\author{
Koko Wahyu Tarnoto ${ }^{1}$ \\ ${ }^{1}$ Magister Ilmu Keperawatan, Universitas Indonesia \\ Diterima : 2 Oktober 2018 , Disetujui : 24 Oktober 2018 \\ e-mail : kokowahyu01@gmail.com
}

\begin{abstract}
Background: The development of information technology has an impact on the world of education in terms of learning systems. E-Learning (Electronic learning) is a webbased virtual education system that has the purpose of helping the process of teaching and learning activities. The method used in this literature study is the type of nonsystematic review. Method: The author searches for the electronic database PROQUEST, Science Direct, Elsevier, BMJ, Google Scholar and PubMed. The author also uses several search keywords namely "Virtual Learning", "Based Learning Avatar", "Nursing Education", Interactive Real Virtual Learning ", " IPE ", " IPC "," Interprofesional Collaboration ", "Interprofessional Education ", "Simulation Skills "by using boolean" AND. Results :"The author uses inclusion and exclusion criteria in conducting filtering articles published in 2013-2018. Conclusion:From the results It is known that E-learning and its various applications that have been applied in the world of nursing education can be used as alternatives in offering learning many benefits: Hope in the future e-learning will become more effective, along with the development of technology and learning methods used
\end{abstract}

Keywords : E-learning; Technology; Nursing Education

\section{PENDAHULUAN}

Perkembangan dunia pendidikan dalam hal sistem pembelajaran. E-Learning (Electronic learning) merupakan sistem pendidikan virtual berbasis web yang mempunyai tujuan utama untuk membantu proses kegiatan belajar mengajar (Susanti, 2008).

Penggunaan metode e-learning, baik blended maupun full online sangat diperlukan terutama untuk pendidikan Keperawatan di Indonesia. Terdapat kurang lebih 288 institusi pendidikan keperawatan di Indonesia yang menyelenggarakan pendidikan keperawatan termasuk jenjang pendidikan Diploma Tiga (DIII), Sarjana (S1), Ners (Ns), Magister dan Doktoral Keperawatan (AIPNI, 2017). Bekerjasama antara Kementerian Pendidikan dan Kementerian Kesehatan Republik Indonesia telah melakukan upaya untuk meningkatkan kualitas pendidikan keperawatan melalui penyelenggaraan sistem akreditasi dan uji kompetensi untuk lulusan perawat. Hal tersebut memberikan pengaruh signifikan bagi institusi pendidikan di indonesia untuk mampu dalam melakukan pengembangan dan peningkatan kualitas mutu pendidikan di institusi masing - masing.

Sebagai negara kepulauan, penggunaan e-learning dapat digunakan sebagai alternatif di dalam institusi 
pendidikan

Kemenristekdikti mengembangkan pembelajaran online sejak tahun 2014 melalui program Sistem Pembelajaran Daring (SPADA) Indonesia (Kemenristekdikti, 2016).

Sistem Pembelajaran Daring (SPADA) Indonesia memiliki produk mata kuliah yang dapat diakses secara daring dimana telah menyediakan 4.829 modul Mata Kuliah Daring dan Mata Kuliah Terbuka untuk 776 Mata Kuliah yang ditawarkan oleh 51 Perguruan Tinggi penyelenggara yang diikuti oleh 14.931 mahasiswa dari 176 Perguruan Tinggi Mitra di seluruh Indonesia (Ristekdikti, 2018). Dalam mengimplementasikan pembelajaran internet bukan berarti sekedar meletakkan materi ajar pada web tetapi skenario pembelajaran perlu juga dipersiapkan secara matang dengan tujuan untuk mengundang keterlibatan peserta didik secara aktif dan konstruktif dalam proses belajar mereka. Beberapa penelitian mengatakan e-learning telah terbukti mampu menyediakan pembelajaran yang cepat, hemat biaya, lebih aksesibel serta akuntabel bagi semua partisipan dalam proses belajar (Supradono, 2015).

Inovasi pengembangan metode pembelajaran dengan menggunakan real avatar based learning di STIKEP PPNI Jawa Barat sangat efektif dalam meningkatkan self direct learning mahasiswa terutama pada aspek peningkatan perencanaan dan implementasi serta self monitoring (Heni Purnama, Dhika Dharmansyah, Nyanyu Nina Putri Calisane, 2017). Menurut Hermansyah, (2017) bahwa sistem $e$ learning dapat meningkatkan kualitas pembelajaran mata kuliah pada Prodi DIV Keperawatan Poltekkes Kemenkes
Banda Aceh sehingga dapat digunakan sebagai sarana yang menunjang proses belajar mengajar dimana tidak hanya mengimplementasikan materi ajar, tetapi juga menciptakan skenario pembelajaran dengan matang untuk mengundang keterlibatan mahasiswa secara aktif dan konstruktif dalam proses belajar mereka.

Berdasarkan fenomena tersebut penulis tertarik untuk membahas kajian literatur dengan judul " E-Learning dan Aplikasinya Dalam Bidang Pendidikan Keperawatan"

\section{METODE PENELITIAN}

Metode yang digunakan penulis adalah kajian studi literatur dengan tipe non-sytematic review. Untuk mengumpulkan data yang berupa artikel, penulis menggunakan beberapa database. Database yang digunakan penulis dalam mencari sumber literatur yang akan dikaji adalah PROQUEST, Science Direct, Elsevier, BMJ, Google Scholar dan PubMed. Penulis juga menggunakan beberapa kunci pencarian yaitu "Virtual Learning", "Avatar Based Learning", "Nursing Education", Interactive Real Virtual Learning", "IPE", "IPC", "InterprofesionalCollabora tion", "Interprofesional Education", "Simulasi Keterampilan" dengan menggunakan boolean "AND". Selain menggunakan kata kunci, penulis juga menggunakan kriteria inklusi dan ekslusi dalam melakukan penyaringan artikel yang ditinjau. Mulai dari artikel terbitan 2013-2018, menggunakan bahasa indonesia dan bahasa inggris serta artikel fulltext dengan sumber yang terpercaya. Dari pencarian di atas didapatkan artikel dan penulis menganalisa dan mengangkat judul " E-Learning Dan Aplikasinya Dalam Bidang Pendidikan Keperawatan". 
Selain itu penulis juga memilih beberapa jurnal sebagai jurnal pendukung untuk menganalisa judul yang sudah ditetapkan oleh penulis.

\section{HASIL PENELITIAN}

Teknologi dan informasi yang berkembang begitu cepatnya merambah ke dalam berbagai aspek kehidupan tanpa terkecuali dalam bidang pendidikan khususnya keperawatan. Perkembangan ini merupakan pemanfaatan inovasi dalam teknologi industri 4.0 yang diharapkan dapat membawa kemajuan menuju perbaikan kualitas pendidikan. Pembaharuan atau inovasi yang harus dilakukan untuk memperbaiki kualitas pendidikan di Indonesia meliputi aspek proses pendidikan, sistem pendidikan yang diterapkan dan proses pembelajaran yaitu inovasi mengenai kurikulum, strategi belajar, metode pengajaran atau model yang diterapkan dalam proses belajar mengajar (Silahuddin, 2015).

Beberapa studi menunjukkan persepsi penggunaan e-learning berbasis web di Poltekkes Kemenkes Aceh efektif. Hal ini didukung oleh fitur dan desain tampilan icon yang mudah dipahami dan ditemukan, kemudian entry dan edit data pada permodelan e-learning telah sesuai, tetapi dalam hal proses pencarian informasi masih belum sesuai harapan terhadap waktu yang dibutuhkan (2-6 detik). Kemudian fungsi bantuan (help) belum sesuai dikarenakan masih terbatasnya rancangan fungsi bantuan dalam permodelan ini sehingga untuk langkah selanjutnya perlu ditambahkan fungsi ini untuk kemudahan bagi user (Hermansyah, 2017). Menyimak dari penelitian tersebut bahwa permodelan elearning yang sudah dirancang ini dapat diterima dan sesuai dengan kebutuhan di institusi prodi D-IV di Poltekkes Kemenkes Aceh.

Fandianta, Sanjaya, (2013) menjelaskan ada perbedaan yang bermakna terhadap peningkatan pengetahuan mahasiswa di Poltekkes Kemenkes Palembang yang mengikuti pembelajaran menggunakan e-learning dibandingkan dengan pembelajaran konvensional. Walaupun baru di intervensi pada satu mata kuliah, penggunaan e-learning tersebut sudah membantu proses belajar menjadi lebih efektif dan membantu ketersediaan bahan ajar, diskusi lebih interaktif, kemudahan dalam pemberian dan penyelesaian tugas dan pelaksanaan kuis/ujian.

Penelitian yang dilakukan oleh Heni Purnama, Dhika Dharmansyah, Nyanyu Nina Putri Calisane, (2017) dengan menggunakan Virtual learning di STIKEP PPNI Jawa Barat merupakan metode pembelajaran yang dinilai efektif dan efisien dalam meningkatkan ketrampilan dan soft skill, maksudnya dalam metode pembelajaran tersebut mahasiswa tidak hanya tahu dan mengerti, namun diharapkan paham dan mampu mengembangkan sendiri ilmu yang mereka peroleh (self directed learning). Metode ini merupakan bagian dari simulasi praktek dan ujian praktek mahasiswa yang di desain hampir sama dengan kondisi rumah sakit. Struktur real avatar based learning terdiri dari interactive real virtual learning (desain laboratorium sesuai dengan rumah sakit), learning task (skenario kasus) dan learning feed back (pencarian studi literatur).

Avatar adalah animasi yang dihasilkan oleh komputer yang dapat mereplikasi komunikasi, tindakan, sikap sesuai dengan setting yang sudah 
ditentukan berdasarkan skenario yang sudah ada (Martin, 2015). Pengembangan teknologi ini yaitu dengan penciptaan avatar untuk pasien yang biasa disebut pasien virtual yaitu bentuk duplikasi dari pasien dalam dunia maya yang dihasilkan oleh aplikasi komputer (Forsberg, et al, 2014). Salah satunya penggunaannya di Universitas Jember Fakultas Kedokteran yaitu K- Nearest Neighbour untuk klasifikasi penilaian pada virtual pasient case untuk penilaian mahasiswa yang sedang tahap OSCE (Objective Structure Clinical Examination) (Eliyen, 2017). Hal ini juga dilakukan pada Universitas Drexel pada program studi Keperawatan yang telah menerapkan virtual pasien khusus untuk pre lisensi perawat dalam melakukan pengkajian fisik sejak tahun 2013.

Pemanfaatan teknologi informasi di Pendidikan Keperawatan juga dilakukan di Australia dengan metode randomized controlled trial yang menunjukkan bahwa avatar based learning efektif dalam meningkatkan ketrampilan mahasiswa keperawatan dari mulai pengkajian sampai dengan evaluasi. Di samping itu mahasiswa juga melaporkan tingkat kepuasan yang tinggi dengan penerapan metode e-learning ini (O'Flaherty, 2014). Studi lain yang dilakukan oleh Calman, (2014) di Amerika Serikat menunjukkan bahwa dengan penggunaan simulasi yang nyata dapat meningkatkan komunikasi dan keterlibatan aktif mahasiswa dalam proses pembelajaran. Selain itu Choi., (2015) menegaskan bahwa penggunaan pembelajaran dengan metode virtual itu bisa diaplikasikan juga untuk tindakan khusus seperti pemasangan Nasogastic Tube (NGT), dimana proses ini jika hanya dilaksanakan praktik saja tanpa ada skenario yang komprehensif tidak akan mampu meningkatkan sense of feeling mahasiswa.

\section{PEMBAHASAN}

Perubahan paradigma di pendidikan mengantarkan pada sebuah penerapan teknologi dalam profesi kesehatan. WHO, (2012) telah membuat sebuah grand design tentang pembentukan karakter kolaborasi dalam bentuk pendidikan formal yaitu berupa Interprofesional Education di ranah pendidikan akademik. IPE adalah strategi pelaksanaan pembelajaran yang diikuti oleh dua atau lebih profesi berbeda untuk meningkatkan kolaborasi dan kualitas pelayanan serta pelaksanaannya dapat dilakukan di semua pembelajaran pada jenjang Sarjana, Pendidik Klinik dengan tujuan untuk menghasilkan tenaga kesehatan yang profesional.

Dalam menjalankan fungsi utama, IPE diharapkan dapat menopang kualitas Interprofesional Collaboration dalam dunia pelayanan khususnya di Rumah Sakit (Graves M, 2016). Dalam pendidikan keperawatan, seorang profesional sangat penting untuk mengakses kompetensi tersebut dikarenakan untuk mengembangkan keterampilan clinical reasoning dan komunikasi dalam profesional kesehatan terutama keperawatan. Salah satu contoh yang dapat digunakan adalah dengan penggunaan serta penerapan aplikasi elearning bagi calon tenaga kesehatan (Powers, Kelly A., et, all, 2017).

Dari pembahasan studi literatur penerapan e-learning di pendidikan keperawatan, pemanfaatan teknologi tersebut mempunyai dampak yang berseberangan ketika digunakan secara baik maka dampaknya akan positif tapi 
sebaliknya jika digunakan untuk hal yang buruk maka dampaknya pun akan buruk juga. Kelemahan dalam menggunakan elearning adalah kreatifitas dari animator (virtual learning untuk menampilkan avatar yang baik dam memiliki karakter serta original dari animator), membutuhkan dukungan anggaran besar, fasilitas sarana dan prasarana yang memadai, dibutuhkan juga ahli teknologi informatika dan desain grafis yang mampu membuat web based and virtual. Selain dalam hal fasilitas diperlukan juga inovasi para tenaga pengajar meskipun memiliki keterbatasan dalam hal fasilitas pendukung.

Sedangkan dilihat dari segi keperawatan, kelemahannya adalah tidak semua mahasiswa bisa menggunakan sistem ini karena beberapa jenis aplikasi dan harus berada di depan layar computer/ smartphone dalam jangka waktu yang cukup lama, dimana ini menjadi kendala tersendiri. Selain itu tingkat kelelahan bisa terjadi dibandingkan dengan model konvensional degan simulasi tatap muka dengan adanya probandus. Hal ini senada dengan penelitian dari (Cobbert, 2016) menyatakan bahwa nilai kelelahan lebih tinggi daripada simulasi tatap muka. Selain itu perlu adanya penilaian lebih lanjut terkait dengan proses tingkat pemahaman dan pengetahuan dari penggunaan E-learning tersebut.

\section{KESIMPULAN DAN SARAN}

Pendidikan di abad 21 yaitu cyber (E-Learning) yang merupakan pembelajaran melalui pemanfaatan teknologi dimana peserta didik berusaha untuk memperoleh bahan belajar dan proses belajar melalui komputer atau internet yang sesuai dengan kebutuhannya. Secara tidak langsung mau atau tidak mau tantangan bagi para pengambil kebijakan dan perancang inovasi e-learning. Oleh karena itu penulis review sependapat bahwa dalam sistem pendidikan konvensional, fungsi elearning adalah untuk memperkaya wawasan dan pemahaman peserta didik serta proses pembiasaan agar melek sumber belajar khususnya teknologi internet. E-learning sebagai suatu alternatif dalam pembelajaran memang menawarkan banyak manfaat dan kegunaan. Bagaimanapun juga e-learning tetap memiliki keterbatasannya sendiri yang patut diperhitungkan oleh setiap pihak yang ingin turut serta dalam proses pengembangan $e$-learning tersebut.

Harapan atas sistem e-learning di masa mendatang akan menjadi semakin efektif seiring dengan semakin berkembangnya teknologi dan metode pembelajaran yang digunakan. Pengembangan sistem E-learning juga diharapkan tidak hanya memperhitungkan masalah finansial dan profitabilitas saja, tetapi juga dapat dijadikan sebagai media strategis dan metode pembelajaran yang aktif, kreatif dan inovatif serta mampu mengimplementasikan dalam kehidupan sehari - hari dengan memperhatikan sisi psikologis peserta didik dan mengakomodasi berbagai kepribadian serta cara belajar.

\section{DAFTAR RUJUKAN}

AIPNI. (2017). AIPNI members in 2017. Retrieved from http://aipniainec.com/id/anggota_list//15

Calman, F. (2014). The Impact Of Multiuser Virtual Environments On Student Engagement. Nurse Education In Practice, 15, 13-16. Retrieved

from 
http://dx.doi.org/10.1016/j.nepr.2 014.11.006.

Choi., et al. (2015). A Virtual Reality Based Simulator For Learning Nasogastric Tube Placement Computer In Biology and Medicine. Journal Compbiomed, 57, 103-115. Retrieved from http://dx.doi.org/10.1016/j.compbi omed.2014.12.006

Cobbert, S. and E. S. (2016). Virtual versus face-to-face clinical simulation in relation to student knowledge, anxiety and self confidence in maternal-newborn nursing: A randomized Controlled Trial. In Nurse Education Today (Vol. 45, pp. 179-184).

Eliyen, K. H. T. M. A. M. (2017). KNearest Neighbor untuk Klasifikasi Penilaian pada Virtual Patient case. Jurnal Arus Elektro Indonesia, 15-18.

Fandianta, Sanjaya, G. Y. (2013). Meningkatkan Pengetahuan Mahasiswa Dengan Memberikan Fleksibilitas Belajar Mengajar Melalui Metode Blended Learning, 2(2), 1-8.

Forsberg, E., Ziegert, K., Hult, H., Fors, U. (2014). Clinical reasoning in nursing, a thinkaloud study using virtual patiens - a base for an innovative assesment. Nurse Education Today, 34 (4). Retrieved from http://dx.doi.org/10.1016/j.nedt.20 13.07.010 [Epub2013 Jul 25]

Graves M, D. S. (2016). Factors affecting interprofessional collaboration when communicating through the use of information and communication technologies: a literature review. Journal Res Interprof Pract Educ, 6, 2.

Heni Purnama, Dhika Dharmansyah, Nyanyu Nina Putri Calisane, L. L. (2017). Inovasi Pengembangan Metode Pembelajaran Dengan Menggunakan Real Avatar-Based Learning Dalam Pendidikan Keperawatan: A Bridge Connection Theory And Practice Di STIKEP PPNI Jawa Barat, 12(3), 150-155.

Hermansyah, M. (2017). Persepsi ELearning berbasis web pada program studi keperawatan banda aceh politeknik kesehatan kemenkes aceh ( Perception of web-based e-learning in the Nursing Study Program of Health Polytechnic at Ministry of Health Aceh ). Aceh Nutrition Journal, 2, 73-79.

Kemenristekdikti. (2016). Sistem pembelajaran Daring (SPADA) Indonesia. Retrieved from http://kuliahdaring.dikti.go.id/s/

Martin, S. (2015). The Rise of the Avatar : Virtual Dimention of"the human"in Nursing Science. Nordic Journal of Nursing, 35, 158-164.

O'Flaherty, J. L. (2014). Nursing Student's Evaluation Of A Virtual Classroom.

Powers, Kelly A., Diamond StatonWilliams, Cory Sheeler, J. H. (2017). Creating collaborative learning opportunities. Nursing Management Journal, 48(1), 9-11. https://doi.org/10.1097/01.NUMA. 0000511189.26042 .40

Ristekdikti. (2018). Menristekdikti Luncurkan E-Learning/ Hybrid Learning, Strategi Pendidikan Tinggi untuk Kaum Milenial. 
Retrieved October 4, 2018, from http://belmawa.ristekdikti.go.id/2 018/05/12/menristekdiktiluncurkan-e-learning-hybridlearning-strategi-pendidikantinggi-untuk-kaum-milenial/

Silahuddin. (2015). Penerapan ELEARNING dalam Inovasi Pendidikan. Jurnal Ilmiah Circuit, 1(1), 48-59.

Supradono, B. (2015). Perancangan pengembangan komprehensif sistem pembelajaran jarak jauh (distance learning) di institusi pergururan tinggi, 31-36.

Susanti, E. dan S. M. (2008). Rancang Bangun Aplikasi E-learning. J.Teknologi, 1 No 1, 53-57.

WHO. (2012). No TitleFramework for Action on Interprofesional Education and Collaborative Practice. Geneva, Switzerland: World Health Organization Press. 